\title{
Unionization Structures, Budget Constraint and Privatization
}

\author{
Mingdian Cai', Yishan Lu², Chu-Chuan $\mathrm{Hsu}^{3^{*}}$ \\ ${ }^{1}$ School of Management Science and Engineering, Baise University, Baise, China \\ ${ }^{2}$ School of Management and Economics, Kunming University of Science and Technology, Kunming, China \\ ${ }^{3}$ Department of Marketing and Logistics Management, Yu Da University of Science and Technology, Taiwan \\ Email: *edison9@ydu.edu.tw
}

How to cite this paper: Cai, M. D., Lu, Y. S., \& Hsu, C.-C. (2020). Unionization Structures, Budget Constraint and Privatization. Modern Economy, 11, 994-1005. https://doi.org/10.4236/me.2020.114073

Received: February 28, 2020

Accepted: April 24, 2020

Published: April 27, 2020

Copyright $(\odot) 2020$ by author(s) and Scientific Research Publishing Inc. This work is licensed under the Creative Commons Attribution International License (CC BY 4.0).

http://creativecommons.org/licenses/by/4.0/

\begin{abstract}
In this paper, we aim to explore the influence of budget constraint privatization policy in the context of mixed duopoly to examine whether privatization policy is dependent upon the unionization structure with labour productivity difference. We showed that, when the unions put equal weights on the wages and the numbers employment, the social welfare pre-privatization is always higher than the one post-privatization regardless of the type of unionization; the government should not privatize the public firm, and nationalization policy should be retained because it will provide a higher rent for the union. Furthermore, union(s) opposes the privatization policy in the presence of budget constraint and union structure.
\end{abstract}

\section{Keywords}

Decentralized Unions, Centralized Union, Productivity Difference, Privatization

\section{Introduction}

State-owned enterprises often have strong unions. In the process of privatization, it may have a redistribution effect on the remuneration of labour unions, and then affect the privatization process of state-owned enterprises. In Europe, countries such as Sweden, Australia, the former West Germany, Italy and the UK are moving towards a more decentralized unionization structure, as shown in Katz (1993). ${ }^{1}$ Haucap et al. (2007) discuss labour market reform in Germany towards a ${ }^{1}$ Under decentralized unions, wage is set between a firm and the firm-specific labour union, while under a centralized union, an industry-wide union negotiates wage for the entire industry. See, for example, Horn and Wolinsky (1988), and Davidson (1988). 
more decentralized unionization structure. ${ }^{2}$ There is another trend of the nationalized firm undergone privatization at the time from developing economies to transitional economies, and being criticized for not having a complete reform schemes.

The strong power of unions of the nationalized firms supported by the political party opposed the privatization policy was also highlighted by the privatization process of the fully nationalized firms. We may anticipate that workers' unions opposed the complete privatization because they reckoned that it was going to be conducted at the expense of workers welfare. It has been recognized that a public firm may not earn positive profit in mixed oligopoly theory. Bennett and La Manna (2012) establish an irrelevance result in a closed economy with budget constraint imposing on the public firm and allowing free private entry. The issue of budget constraint is being raised in a different context of a mixed market. ${ }^{3}$ Choi (2011a) considers the budget-constraint problem in a unionized mixed oligopoly where the government decides whether or not to impose a budget on a public firm. ${ }^{4}$ Choi (2011b) takes the government's preference for tax revenues into the theoretical framework of unionized mixed oligopolies, and investigates the efficiency of privatization. The above results differ from Ishida and Matsushima's (2009) findings that in a unionized mixed duopoly, tightening budget constraints can enhance social welfare when the public firm is as efficient as private firms.

The research on privatization policy is numerous (see De Fraja \& Delbono, 1989; De Fraja \& Delbono, 1990; Matsumura, 1998; Wang \& Chen, 2010 and thereafter), the implications of unionization structure on whether the public firm should be privatized were seldom thoroughly analyzed. ${ }^{5}$ Liu and Lo (2007) study the structure of union-wage Nash bargaining and it's implication on privatization, and show that centralized bargaining is better than decentralized bargaining for welfare improvement. But they do not consider the influence of labor productivity difference, budget constraint of public firm, and discriminatory wages. Tsai et al. (2019) explore the influence of union structures and wage pricing strategies on the welfare under a mixed oligopoly which has a public firm with budget constraint. They showed that, the government should restrict the centralized union formed by the public and the private firm to charge discriminatory wages, and to avoid the improper use of the monopoly power of the labour union. However, the above two papers did not consider an important issue: should the government ${ }^{2}$ As discussed extensively in Haucap et al. (2007), a recommendation for the labour market reform in Germany was to move from the area tariff system, which is similar to our case of a centralized union, to a more flexible wage negotiation within the area tariff system or even to a decentralized wage negotiation where competition occurs among the independent firm-union pairs, as in our decentralized unionization structure. The trend over the past decades towards more decentralized unions can also be found in the OECD (2004).

${ }^{3}$ See De Fraja and Delbono (1989) for the specification of the public firm in mixed oligopoly and De Fraja and Delbono (1990) for the general review of mixed oligopoly models.

${ }^{4}$ Wang et al. (2014) show that in the presence of cross-ownership associated with an improvement of production inefficiency of the public firm, the optimal privatization policy is full privatization whether budget constraints are imposed on the public firm.

${ }^{5}$ For literature on union bargaining in mixed oligopoly, see De Fraja (1993), Willner (1999), Gronblom and Willner (2008), Ishida and Matsushima (2009) and Choi (2011a). 
privatize the public firm? ${ }^{6}$

In this paper, we aim to explore the influence of budget constraint on privatization policy in the context of mixed duopoly to examine whether privatization policy is dependent upon the unionization structure with labour productivity difference. ${ }^{7}$ Major findings are that: 1 ) When the unions put equal weights on the wages and the numbers of employment, the government should not privatize the public firm, and nationalization policy should be retained. 2) Privatization policy is neutral in the presence of budget constraint and union structure. 3) When the union of private firm cares more about the numbers of employment, privatization is the optimal policy and compatible with the interest of unions in decentralization union.

The rest of the paper is organized as follows. Section 2 presents the unionized mixed duopoly and the results. Section 3 examines the unionized pure duopoly and the results. Section 4 explores the decision on whether to privatize by the government in the presence of union structures. Section 5 concludes.

\section{Pre-Privatization and Unionization Structures}

Following Tsai et al. (2019), we consider an economy with two final goods producers, firms 1 and 2. These firms produce a homogeneous product. Assuming that the inverse market demand function for the product is $p=1-q$, where $p$ is price and $q=q_{1}+q_{2}$ is the total output. Assume that firm 1 requires one worker to produce one unit of output, while firm 2 requires $\lambda$ workers to produce one unit of output, where $\lambda>1 .{ }^{8}$ The difference in labour coefficients, which may be the outcome of a labour saving innovation by firm 1, as in Mukherjee and Pennings (2011), creates different labour productivities in the firms. The labour productivity in firm 1 is 1 and in firm 2 , it is $\frac{1}{\lambda} \cdot{ }^{9}$ Both firms require only workers to produce the product and the firms hire workers from labour unions. ${ }^{10}$

\footnotetext{
${ }^{6}$ Low productivity of the public firm results from two factors, one is its low operating efficiency and another one is seldom mentioned for the policies burden which decreases the incentives resulting moral hazard, and shirking on work efforts and suffering negative profit.

${ }^{7}$ In Choi (2011a), decentralized unions are considered under unionized mixed duopoly without productivity difference, but focus on the role of strategic budget constraints. From his analysis, we could infer that total utilities in the presence of budget constraints are higher than the one in the absence of budget constraints, while the utility of the private firm remains the same.

${ }^{8}$ The public firm has a lower labor productivity which may highly due to shirking behavior in the large-size public sector. Hence, public firms are less efficient than private firms. Many empirical works do not support this view (and many other papers do support this view). Using constant marginal costs and assuming cost differences between public and private firms can be found in Mujumdar and Pal (1998), Pal (1998), Matsumura (2003), Matsumura and Ogawa (2010), and Wang et al. (2010). Note that the linearly increasing marginal cost function is more general, which is used in De Fraja and Delbono (1989), Bárcena-Ruiz and Garzón (2006), Wang and Wang (2009) and Wang et al. (2014) for the specification of linearly increasing marginal cost function under mixed oligopoly.

${ }^{9}$ See Mukherjee (2010), Mukherjee et al. (2012), and Mukherjee and Wang (2013) using the same parameter for labor productivity difference.

${ }^{10}$ This study differs from Wang et al. (2012) in which labors are homogeneous, but allow firm heterogeneity and wages in unionized labor markets for the purposes of the analyzing the decision-making of privatization policy. We appreciate the referee pointed out the relevancy of this paper.
} 
We will consider two types of labour unions: Firstly, Decentralized unions, where the firm-specific labour unions set wages for respective firms. Secondly, a centralized union, where an industry-wide labour union sets wage for all firms. As Yoshida (2000), it can be argued that a centralized union prefers discriminatory wages than a uniform wage. However, the government regulation may induce a centralized union to set a uniform wage (Katz, 1987; DeGraba, 1990; Haucap et al., 2001). We also consider both uniform and discriminatory wages under a centralized union.

In a mixed economy with two final goods producers, private firm 1 and public firm 2 producing a homogeneous product. The private firm as usual maximizes its profit. The public firm concerns about social welfare

$S W=C S+\pi_{1}+\pi_{2}+u_{1}+u_{2}$ but subject to the nonnegative profit constraint. $C S$ is the consumer surplus, $C S=q^{2} / 2$.

We consider the following game. At stage 1, the unions set wage. At stage 2, firms 1 and 2 choose the outputs simultaneously, and the profits are realised. The backward induction is used to derive the subgame perfect Nash equilibrium (SPNE).

When there is a union in each firm, the wage is determined by the bargain result between union and its corresponding firm. Let the reserved wage be $\bar{w}$, then the utility functions of each union are

$$
u_{i}=\left(w_{i}-\bar{w}\right)^{\theta} l_{i}, \quad i=1,2
$$

The importance a union attaches to the wage is assigned as $\theta$ (Leahy \& Montagna, 2000; Lommerud et al., 2003, 2006; Haucap \& Wey, 2004; Choi, 2011a, 2011b). $\theta$ denotes the preference of the union. When $\theta=1$, the unions put equal weights on the wages and the numbers of the employment; when $\theta=0$, the unions care about the numbers of the employment only. In recent year, craft unions are negotiating with enterprises, and most of the disputes are focused on labor conditions, and therefore can be regarded as equal importance. To be able to focus on the purpose of this paper, the following assumptions are made: $\theta=1$, and the reservation wage of the workers is normalised to zero.

First, determine the equilibrium outputs of the firms when the firm $i$ faces the wage rate $w_{i}, i=1,2$. Firms 1 and 2 maximise $\pi_{1}=\left(1-q-w_{1}\right) q_{1}$ and $S W$ subject to budget constraint $\pi_{2} \geq 0$ to determine $q_{1}$ and $q_{2}$ respectively. The public firm 2's maximized problem is

$$
\begin{gathered}
\max _{q_{2}} S W \\
\text { s.t. } \pi_{2}=\left(p-\lambda w_{2}\right) q_{2} \geq 0
\end{gathered}
$$

As in Ishida and Matsushima (2009), the constraint implies there is some lower-bound restriction on the public firm's profit, that is, the public firm faces a budget constraint. Denoting $\alpha$ as the multiplier of the budget constraint, the Lagrangian equation can be written as

$$
L=S W+\alpha \pi_{2}
$$


Taking $w_{i}$ as given, the first-order conditions are given by

$$
\begin{gathered}
\frac{\partial L}{\partial q_{2}}=(1+\alpha)\left(1-q_{1}\right)-(1+2 \alpha) q_{2}-(1+\alpha) \lambda w_{2}+\lambda w_{2}=0 \\
\frac{\partial L}{\partial \alpha} \alpha=\alpha\left(1-q_{1}-q_{2}-\lambda w_{2}\right) q_{2}=0
\end{gathered}
$$

The first-order condition for the private firm is given by

$$
\frac{\partial \pi_{1}}{\partial q_{1}}=1-2 q_{1}-q_{2}-w_{1}=0
$$

Solving the first-order conditions (2), (3) and (4), we obtain the equilibrium outputs

which are

$$
q_{1}^{*}=\lambda w_{2}-w_{1}, \quad q_{2}^{*}=1+w_{1}-2 \lambda w_{2}, \text { and } \alpha^{*}=\frac{\lambda w_{2}}{q_{2}^{*}}>0 . .^{11}
$$

Now determine the wages set by the unions. We consider the right-to-manage model of labour union, as in Haucap and Wey (2004) and Mukherjee (2008), to name a few. ${ }^{12}$ We assume that the unions determine wage to maximise their utilities and the firms hire workers according to their needs. To prove our result in the simplest way, we follow, e.g., Haucap and Wey (2004) and Mukherjee (2008), to assume that the unions have full bargaining power. In the decentralized unions, we have following lemma immediately.

Lemma 1: In the decentralized unions under mixed duopoly, the equilibrium is (denotes by $M, d$ on superscript)

$$
\begin{aligned}
& w_{1}^{M, d}=\frac{1}{7}, w_{2}^{M, d}=\frac{2}{7 \lambda}, u_{1}^{M, d}=\frac{1}{49}, u_{2}^{M, d}=\frac{8}{49}, \\
& q_{1}^{M, d}=\frac{1}{7}, q_{2}^{M, d}=\frac{4}{7}, C S^{M, d}=\frac{25}{98}, S W^{M, d}=\frac{45}{98} .
\end{aligned}
$$

Next, we then consider a centralized union. If the centralized union charges discriminatory wages, it determines $w_{1}$ and $w_{2}$ to maximise $U^{c, d}=u_{1}^{c, d}+u_{2}^{c, d}=\lambda w_{2}\left(1+2 w_{1}-2 \lambda w_{2}\right)-w_{1}^{2}$. We have following lemma immediately.

Lemma 2: In the centralized union scenario with discriminatory wages, the equilibrium is (denotes by $M, c, d$ on superscript)

$$
\begin{aligned}
& w_{1}^{M, c, d}=\frac{1}{2}, w_{2}^{M, c, d}=\frac{1}{2 \lambda}, U^{M, c, d}=\frac{1}{4}, q_{1}^{M, c, d}=0, \\
& q_{2}^{M, c, d}=\frac{1}{2}, C S^{M, c, d}=\frac{1}{8}, S W^{M, c, d}=\frac{3}{8} .
\end{aligned}
$$

With binding budget constraint, the profit will be zero for the public firm and ${ }^{11}$ It means that $\pi_{2}^{*}=0$, and the budget constraint is binding. If we do not impose the zero profit condition for the public firm, the public firm's production decision may lead to negative profit.

${ }^{12}$ The "efficient bargaining" model, which stipulates that the firms and the unions bargain over wages and employment, is an alternative to the right-to-manage model. See, Layard et al. (1991) for arguments in favour of the right-to-manage models. 
the union in the public firm will gain more rent accordingly. ${ }^{13}$ The centralized union charges discriminatory wages and because the low productivity is for the public firm, the union will employ more workers and force the private firm to close the shop in order to gain more rent. Under such circumstance, the utility of the centralized union is higher than the decentralized unions, but the social welfare comparison is the opposite.

If the centralized union charges a uniform wage, i.e., $w_{1}=w_{2}=w$, it determines $w$ to maximise $U^{c, u}=u_{1}^{c, u}+u_{2}^{c, u}=w[\lambda-w(1+2(\lambda-1) \lambda)]$. We have following lemma immediately.

Lemma 3: In the centralized unions scenario with uniform wage, the equilibrium are (denotes by $M, c, u$ on superscript)

$$
\begin{aligned}
& w^{M, c, u}=\frac{\lambda}{2+4(\lambda-1) \lambda}, U^{M, c, u}=\frac{\lambda^{2}}{4+8(\lambda-1) \lambda}, q_{1}^{M, c, u}=\frac{(\lambda-1) \lambda}{2+4(\lambda-1) \lambda}, \\
& q_{2}^{M, c, u}=\frac{2+\lambda(2 \lambda-3)}{2+4(\lambda-1) \lambda}, C S^{M, c, u}=\frac{(2+\lambda(3 \lambda-4))^{2}}{8(1+2(\lambda-1) \lambda)^{2}}, \\
& S W^{M, c, u}=\frac{(2+\lambda(3 \lambda-4))(2+\lambda(5 \lambda-4))}{8(1+2(\lambda-1) \lambda)^{2}} .
\end{aligned}
$$

\section{Post-Privatization and Unionization Structures}

In this section, we examine the scenario in which both firms are profit maximizers. First, determine the equilibrium outputs of the firms when the firm $i$ faces the wage rate $w_{i}, i=1,2$. Firm 1 and 2 maximise $\pi_{1}=\left(1-q-w_{1}\right) q_{1}$ and $\pi_{2}=\left(1-q-\lambda w_{2}\right) q_{2}$ to determine $q_{1}$ and $q_{2}$ respectively. The equilibrium outputs are

$$
q_{1}^{*}=\frac{1}{3}\left(1-2 w_{1}+\lambda w_{2}\right) \text { and } q_{2}^{*}=\frac{1}{3}\left(1+w_{1}-2 \lambda w_{2}\right)
$$

If there are decentralized unions, union 1 (which is paired with firm 1) sets $w_{1}$ and union 2 (which is paired with firm 2) sets $w_{2}$ to maximise $u_{1}^{d}=\frac{1}{3} w_{1}\left(1-2 w_{1}+\lambda w_{2}\right)$ and $u_{2}^{d}=\frac{1}{3} \lambda w_{2}\left(1+w_{1}-2 \lambda w_{2}\right)$ respectively. We have the following lemma.

Lemma 4: In the decentralized unions under private duopoly, the equilibrium is (denotes by $P, d$ on superscript)

$$
\begin{aligned}
& w_{1}^{P, d}=\frac{1}{3}, w_{2}^{P, d}=\frac{1}{3 \lambda}, u_{1}^{P, d}=u_{2}^{P, d}=\frac{2}{27}, \\
& q_{1}^{P, d}=q_{2}^{P, d}=\frac{2}{9}, C S^{P, d}=\frac{8}{81}, S W^{P, d}=\frac{28}{81} .
\end{aligned}
$$

Next consider a centralized union. If the centralized union charges discriminatory wages, it determines $w_{1}$ and $w_{2}$ to maximise $U^{c, d}=\frac{1}{3}\left[\lambda w_{2}\left(1-2 \lambda w_{2}\right)-2 w_{1}^{2}+w_{1}\left(1+2 \lambda w_{2}\right)\right]$. We have the following lemma.

${ }^{13} \mathrm{We}$ appreciate the referees pointed out that this result is based on the assumption that the union has full bargaining power. 
Lemma 5: In the centralized union under private duopoly with discriminatory wages, the equilibrium is (denotes by $P, c, d$ on superscript)

$$
\begin{aligned}
& w_{1}^{P, c, d}=\frac{1}{2}, w_{2}^{P, c, d}=\frac{1}{2 \lambda}, U^{P, c, d}=\frac{1}{6}, \\
& q_{1}^{P, c, d}=q_{2}^{P, c, d}=\frac{1}{6}, C S^{P, c, d}=\frac{1}{18}, S W^{P, c, d}=\frac{5}{18} .
\end{aligned}
$$

If the centralized union charges a uniform wage, i.e., $w_{1}=w_{2}=w$, it determines $w$ to maximise $U^{c, u}=\frac{1}{3} w[1+\lambda-2 w(1+(\lambda-1) \lambda)]$.

Lemma 6: In the centralized union under private duopoly with uniform wages, the equilibrium is (denotes by $P, c, u$ on superscript)

$$
\begin{aligned}
& w^{P, c, u}=\frac{1+\lambda}{4\left(1+\lambda^{2}-\lambda\right)}, U^{P, c, u}=\frac{(1+\lambda)^{2}}{24(1+(\lambda-1) \lambda)}, \\
& q_{1}^{P, c, u}=\frac{5}{12}-\frac{1}{4(1+(\lambda-1) \lambda)}, q_{2}^{P, c, u}=\frac{5+\lambda(2 \lambda-5)}{12(1+(\lambda-1) \lambda)}, \\
& C S^{P, c, u}=\frac{(7+\lambda(7 \lambda-10))^{2}}{288(1+(\lambda-1) \lambda)^{2}}, \\
& S W^{P, c, u}=\frac{(7+\lambda(7 \lambda-10))(17+\lambda(17 \lambda-14))}{288(1+(\lambda-1) \lambda)^{2}} .
\end{aligned}
$$

The centralized union charges a uniform wage, we restrict our attention to $\lambda \in[1,2]$, since it ensures that the union supplies workers to both firms rather than to firm 1 (i.e., the more productive firm) only (Mukherjee et al., 2012).

\section{Union Bargaining and the Decision on Whether to Privatize}

From the analysis provided in the previous section, we first see that $w_{1}^{M, d}<w_{2}^{M, d}<w^{M, c, u}$ if $(1<\lambda<2)$ when the difference on labour productivity is small, indicating under decentralized union, the bargaining wage for the public firm will be higher than the one for the private firm (i.e. $w_{1}^{M, d}=\frac{1}{7}$ and $\left.w_{2}^{M, d}=\frac{2}{7 \lambda}, w_{1}^{M, d}<w_{2}^{M, d}\right)$. In pure duopoly without having a public firm, the low wage is paid by the low productive firm under decentralized union (i.e. $w_{1}^{P, d}=\frac{1}{3}$ and $\left.w_{2}^{P, d}=\frac{1}{3 \lambda}, w_{1}^{P, d}>w_{2}^{P, d}\right)$, while when the difference on labour productivity is large $(\lambda>2)$, the low wage is paid by the low productive firm irrespective of the type of union.

Next, note that under decentralized union, the bargaining wages under mixed duopoly is always less than the one under pure duopoly (i.e. $w_{1}^{M, d}=\frac{1}{7}$, $w_{2}^{M, d}=\frac{2}{7 \lambda}, \quad w_{1}^{P, d}=\frac{1}{3}$ and $w_{2}^{P, d}=\frac{1}{3 \lambda}$, then $w_{1}^{P, d}>w_{1}^{M, d}$ and $\left.w_{2}^{P, d}>w_{2}^{M, d}\right) ;$ under centralized union with discriminatory wage, the bargaining wages under 
mixed duopoly is identical to those under pure duopoly (i.e. $w_{1}^{M, c, d}=\frac{1}{2}$, $w_{2}^{M, c, d}=\frac{1}{2 \lambda} \quad, \quad w_{1}^{P, c, d}=\frac{1}{2} \quad$ and $\quad w_{2}^{P, c, d}=\frac{1}{2 \lambda} \quad$, then $\quad w_{1}^{P, c, d}=w_{1}^{M, c, d} \quad$ and $\left.w_{2}^{P, c, d}=w_{2}^{M, c, d}\right)$, regardless of the different objective functions pursed by the firms.

We have the following proposition.

Proposition 1: Under decentralized union, the bargaining wages under mixed duopoly is always less than the one under pure duopoly, under centralized union with discriminatory wage, the bargaining wages under mixed duopoly is identical to those under pure duopoly regardless of the different objective functions pursed by the firms.

Next, from the viewpoint of union interest, the utility of centralized union with discriminatory wages is higher than the sum of utilities under decentralized unions regardless of whether it is mixed or pure duopoly (i.e. $u_{1}^{P, d}+u_{2}^{P, d}=\frac{4}{27}$, $U^{P, c, d}=\frac{1}{6}, \quad u_{1}^{M, d}+u_{2}^{M, d}=\frac{9}{49}$ and $U^{M, c, d}=\frac{1}{4}$, then $u_{1}^{P, d}+u_{2}^{P, d}<U^{P, c, d}$ and $\left.u_{1}^{M, d}+u_{2}^{M, d}<U^{M, c, d}\right)$. The utility of centralized union with discriminatory wages is higher than the sum of utilities under decentralized unions regardless of whether it is mixed or pure duopoly.

In addition, the utility of centralized union and the sum of utilities under decentralized unions at mixed duopoly are higher than the counterparts at pure duopoly (i.e. $u_{1}^{P, d}+u_{2}^{P, d}<u_{1}^{M, d}+u_{2}^{M, d}, U^{P, c, u}<U^{M, c, u 14}$ and $U^{P, c, d}<U^{M, c, d}$ ), and the reasoning for such result is that the low productive firm will produce more and hires more workers to pursue social welfare, which will lead to a higher union utility. We relegate the equilibrium values of union utilities to Table 1.

We have the following proposition.

Proposition 2: Union(s) opposes the privatization policy.

Proof: As Table 1's results show.

Finally, it remains for us to study whether the government should privatize the public firm or not under different union structure. We relegate the equilibrium values of social welfare to Table 2 .

Table 1. Equilibrium union utilities: Pre-privatization and Post-privatization.

\begin{tabular}{ccc}
\hline & Pre-privatization & Post-privatization \\
\hline Decentralized unions & $u_{1}^{M, d}+u_{2}^{M, d}=\frac{9}{49}$ & $u_{1}^{P, d}+u_{2}^{P, d}=\frac{4}{27}$ \\
$\begin{array}{c}\text { Centralized union with } \\
\text { discriminatory wages } \\
\begin{array}{c}\text { Centralized union with } \\
\text { uniform wage }\end{array}\end{array} U^{M, c, d}=\frac{1}{4}$ & $>$ & $U^{p, c, d}=\frac{1}{6}$ \\
\hline
\end{tabular}

\footnotetext{
${ }^{14}$ See Appendix 1.
} 
M. D. Cai et al.

Table 2. Equilibrium social welfare: Pre-privatization and Post-privatization.

\begin{tabular}{|c|c|c|c|}
\hline & Pre-privatization & & Post-privatization \\
\hline Decentralized unions & $S W^{M, d}=\frac{45}{98}$ & $>$ & $S W^{P, d}=\frac{28}{81}$ \\
\hline $\begin{array}{l}\text { Centralized union with } \\
\text { discriminatory wages }\end{array}$ & $S W^{M, c, d}=\frac{3}{8}$ & $>$ & $S W^{P, c, d}=\frac{5}{18}$ \\
\hline $\begin{array}{l}\text { Centralized union with } \\
\text { uniform wage }{ }^{15}\end{array}$ & $S W^{M, c, u}=\frac{(2+\lambda(3 \lambda-4))(2+\lambda(5 \lambda-4))}{8(1+2(\lambda-1) \lambda)^{2}}$ & $>$ & $S W^{p, c, u}=\frac{(7+\lambda(7 \lambda-10))(17+\lambda(17 \lambda-14))}{288(1+(\lambda-1) \lambda)^{2}}$ \\
\hline
\end{tabular}

From Table 2, social welfare pre-privatization is always higher than that of post-privatization regardless of the type of unionization. It implies that the government should not privatize the public firm and this nationalization policy should get the support from the union since it will retain a higher rent for the union. The following proposition is immediate.

Proposition 3: Nationalization is the optimal policy and compatible with the interest of unions.

Proof: As Table 2's results show.

\section{Conclusion}

In this paper, we examined the issue of unionization structures and privatization of public firm with budget constraint. We showed that, when the unions put equal weights on the wages and the numbers employment, the social welfare pre-privatization is always higher than the one post-privatization regardless of the type of unionization; the government should not privatize the public firm, and nationalization policy should be retained because it will provide a higher rent for the union. Furthermore, union(s) opposes the privatization policy in the presence of budget constraint and union structure.

\section{Conflicts of Interest}

The authors declare no conflicts of interest regarding the publication of this paper.

\section{References}

Bárcena-Ruiz, J. C., \& Garzón, M. B. (2006). Mixed Oligopoly and Environmental Policy. Spanish Economic Review, 8, 139-160. https://doi.org/10.1007/s10108-006-9006-y

Bennett, J., \& La Manna, M. (2012). Mixed Oligopoly, Public Firm Behavior, and Free Private Entry. Economics Letters, 117, 767-769. https://doi.org/10.1016/j.econlet.2012.08.025

Choi, K. (2011a). Strategic Budget Constraints in a Unionized Mixed Oligopoly. Japanese Economic Review, 62, 504-516. https://doi.org/10.1111/j.1468-5876.2010.00521.x

Choi, K. (2011b). Unions, Government's Preference, and Privatization. Economic Modelling, 28, 2502-2508. https://doi.org/10.1016/j.econmod.2011.06.025

\section{${ }^{15}$ See Appendix 1.}


Davidson, C. (1988). Multiunit Bargaining in Oligopolistic Industries. Journal of Labor Economics, 6, 397-422. https://doi.org/10.1086/298189

De Fraja, G. (1993). Union and Wages in Public and Private Firms: A Game Theoretic Analysis. Oxford Economic Papers, 45, 457-469. https://doi.org/10.1093/oxfordjournals.oep.a042102

De Fraja, G., \& Delbono, F. (1989). Alternative Strategies of a Public Enterprise in Oligopoly. Oxford Economic Papers, 41, 302-311. https://doi.org/10.1093/oxfordjournals.oep.a041896

De Fraja, G., \& Delbono, F. (1990). Game Theoretic Models of Mixed Oligopoly. Journal of Economic Surveys, 4, 1-17. https://doi.org/10.1111/j.1467-6419.1990.tb00077.x

DeGraba, P. (1990). Input Market Price Discrimination and the Choice of Technology. American Economic Review, 80, 1246-1253.

Gronblom, S., \& Willner, J. (2008). Privatization and Liberalization: Costs and Benefits in the Presence of Wage-Bargaining. Annals of Public and Cooperative Economics, 79, 133-160. https://doi.org/10.1111/j.1467-8292.2007.00356.x

Haucap, J., \& Wey, C. (2004). Unionisation Structures and Innovation Incentives. Economic Journal, 114, C149-C165. https://doi.org/10.1111/j.0013-0133.2004.00203.x

Haucap, J., Pauly, U., \& Wey, C. (2001). Collective Wage Setting When Wages Are Generally Binding: An Antitrust Perspective. International Review of Law and Economics, 21, 287-307. https://doi.org/10.1016/S0144-8188(01)00061-8

Haucap, J., Pauly, U., \& Wey, C. (2007). A Cartel Analysis of the German Labor Institutions and Its Implications for Labor Market Reforms. Journal of Institutional and Theoretical Economics, 163, 503-516. https://doi.org/10.1628/093245607781871381

Horn, H., \& Wolinsky, A. (1988). Bilateral Monopolies and Incentives for Merger. Rand Journal of Economics, 19, 408-419. https://doi.org/10.2307/2555664

Ishida, J., \& Matsushima, N. (2009). Should Civil Servants be Restricted in Wage Bargaining? A Mixed-Duopoly Approach. Journal of Public Economics, 93, 634-646. https://doi.org/10.1016/j.jpubeco.2008.11.004

Katz, H. C. (1993). The Decentralisation of Collective Bargaining: A Literature Review and Comparative Analysis. Industrial and Labor Relations Review, 47, 3-22. https://doi.org/10.1177/001979399304700101

Katz, M. L. (1987). The Welfare Effects of Third-Degree Price Discrimination in Intermediate Good Markets. American Economic Review, 77, 154-167.

Layard, R., Nickell, S., \& Jackman, R. (1991). Unemployment, Macroeconomic Performance and the Labour Market. Oxford: Oxford University Press.

Leahy, D., \& Montagna, C. (2000). Unionisation and Foreign Direct Investment: Challenging Conventional Wisdom? Economic Journal, 110, C80-C92. https://doi.org/10.1111/1468-0297.00522

Liu, T. G., \& Lo, L. F. (2007). Union-Wage Bargaining and Privatization in Mixed Duopoly. Asia-Pacific Economic and Management Review, 10, 1-22.

Lommerud, K. E., Meland, F., \& Sorgard, L. (2003). Unionised Oligopoly, Trade Liberalisation and Location Choice. Economic Journal, 113, 782-800. https://doi.org/10.1111/1468-0297.t01-1-00154

Lommerud, K. E., Straume, O. R., \& Sorgard, L. (2006). National versus International Mergers in Unionized Oligopoly. Rand Journal of Economics, 37, 212-233. https://doi.org/10.1111/j.1756-2171.2006.tb00013.x

Matsumura, T. (1998). Partial Privatization in Mixed Duopoly. Journal of Public Economics, 70, 473-483. https://doi.org/10.1016/S0047-2727(98)00051-6 
Matsumura, T. (2003). Stackelberg Mixed Duopoly with a Foreign Competitor. Bulletin of Economic Research, 55, 275-287. https://doi.org/10.1111/1467-8586.00175

Matsumura, T., \& Ogawa, A. (2010). On the Robustness of Private Leadership in Mixed Duopoly. Australian Economic Papers, 49, 149-160. https://doi.org/10.1111/j.1467-8454.2010.00393.x

Mujumdar, S., \& Pal, D. (1998). Effects of Indirect Taxation in a Mixed Oligopoly. Economics Letter, 58, 199-204. https://doi.org/10.1016/S0165-1765(97)00264-4

Mukherjee, A. (2008). Unionised Labour Market and Strategic Production Decision of a Multinational. Economic Journal, 118, 1621-1639. https://doi.org/10.1111/j.1468-0297.2008.02183.x

Mukherjee, A. (2010). Licensing in a Vertical Structure. In B. A. Everett, \& N. L. Trijillo (Eds.), Technology Transfer and Intellectual Property Issues. New York: Nova Science Publishers.

Mukherjee, A., \& Pennings, E. (2011). Unionization Structure, Licensing and Innovation. International Journal of Industrial Organization, 29, 232-241. https://doi.org/10.1016/j.ijindorg.2010.06.001

Mukherjee, A., \& Wang, L. F. S. (2013). Labor Union, Entry and Consumer Welfare. Economics Letters, 120, 603-605. https://doi.org/10.1016/j.econlet.2013.06.032

Mukherjee, A., Broll, U., \& Mukherjee, S. (2012). Bertrand versus Cournot Competition in a Vertical Structure: A Note. The Manchester School, 80, 545-559.

https://doi.org/10.1111/j.1467-9957.2012.02228.x

OECD (2004). OECD Employment Outlook. Paris, France.

Pal, D. (1998). Endogenous Timing in a Mixed Oligopoly. Economics Letter, 61, 181-185. https://doi.org/10.1016/S0165-1765(98)00115-3

Tsai, T. C., Cheng, K. F., Hsu, C., Tsai, C., Chen, C., \& Lee, J. (2019). Does Uniform Wage Decline the Welfare in a Budget-Constraint Mixed Market? Modern Economy, 10, 474-483. https://doi.org/10.4236/me.2019.102032

Wang, L. F. S., \& Chen, T. L. (2010). Do Cost Efficiency Gap and Foreign Competitors Matter Concerning Optimal Privatization Policy at the Free Entry Market? Journal of Economics, 100, 33-49. https://doi.org/10.1007/s00712-010-0117-4

Wang, L. F. S., \& Wang, J. (2009). Environmental Taxes in a Differentiated Mixed Duopoly. Economic Systems, 33, 389-396. https://doi.org/10.1016/j.ecosys.2009.08.002

Wang, L. F. S., Hsu, C. C., \& Han, T. D. (2012). Partial Privatization and Strategic Budget Constraints in Unionized Mixed Duopoly with Firm Heterogeneity. Mimeo.

Wang, L. F. S., Hsu, C. C., \& Lee, J. Y. (2014). Do Partial Cross Ownership and Budget Constraints Matter for Privatization Policy? Journal of Industry, Competition and Trade, 14, 519-529. https://doi.org/10.1007/s10842-013-0174-9

Wang, L. F. S., Wang, J., \& Lee, J. Y. (2010). Optimum-Welfare and Maximum-Revenue Tariffs in Mixed Oligopoly with Foreign Competitors. Australian Economic Papers, 49, 60-72. https://doi.org/10.1111/j.1467-8454.2010.00387.x

Willner, J. (1999). Policy Objectives and Performance in a Mixed Market with Bargaining. International Journal of Industrial Organization, 17, 137-145. https://doi.org/10.1016/S0167-7187(97)00036-2

Yoshida, Y. (2000). Third-Degree Price Discrimination in Input Market. American Economic Review, 90, 240-246. https://doi.org/10.1257/aer.90.1.240 


\section{Appendix 1}

Comparing the equilibrium union utilities and social welfares, we obtain that

$$
\begin{aligned}
U^{M, c, u}-U^{P, c, u} & =\frac{\lambda^{2}}{4+8(\lambda-1) \lambda}-\frac{(1+\lambda)^{2}}{24(1+(\lambda-1) \lambda)} \\
& =\frac{(2 \lambda-1)\left(1+2 \lambda-3 \lambda^{2}+2 \lambda^{3}\right)}{24\left(1-\lambda+\lambda^{2}\right)\left(1-2 \lambda+2 \lambda^{2}\right)}>0
\end{aligned}
$$

and

$$
\begin{aligned}
& S W^{M, c, u}-S W^{P, c, u} \\
& =\frac{(2+\lambda(3 \lambda-4))(2+\lambda(5 \lambda-4))}{8(1+2(\lambda-1) \lambda)^{2}}-\frac{(7+\lambda(7 \lambda-10))(17+\lambda(17 \lambda-14))}{288(1+(\lambda-1) \lambda)^{2}} \\
& =\frac{\left(5-12 \lambda+13 \lambda^{2}-8 \lambda^{3}+4 \lambda^{4}\right)\left(5-12 \lambda+25 \lambda^{2}-20 \lambda^{3}+16 \lambda^{4}\right)}{288\left(1-\lambda+\lambda^{2}\right)^{2}\left(1-2 \lambda+2 \lambda^{2}\right)^{2}} \\
& >0
\end{aligned}
$$

